\section{Commentary: Closing the gap on bicuspid aortic valve repair}

\author{
Keyan Mobli, MD, and Abe DeAnda, Jr, MD
}

The evolution of mitral valve surgery has progressed from complete replacement to replacement with preservation of the subvalvular apparatus to repair. Complementing this evolution was a detailed understanding of the anatomy and function of all components of the valve and subvalvular mechanism. There should be little doubt that one could have been achieved without the other. We are now following a similar pathway with the aortic valve and the functional aortic annulus. Although not a procedure adopted by all surgeons, preservation of the aortic valve either de novo ${ }^{1}$ or as part of a valve-sparing root replacement has been well described for the trileaflet aortic valve (Figure 1). The bicuspid aortic valve (BAV) adds an additional layer to the challenge of repairing the aortic valve, and repair strategies have been developed, evaluated, and championed by centers of excellence, most notably our friends in Belgium.

In this invited review, Jahanyar and colleagues ${ }^{3}$ use their extensive experience with $>1000$ aortic valve repairs to classify the BAV with an anatomic scheme that combines the Sievers classification ${ }^{4}$ with 3 phenotypes determined by the commissural angulation. This understanding of the variations in orientation of the commissure and angulation, as well as an appreciation of the differences in a functional aortic annulus, has important implications for a confident repair. In their analysis of their institutional experience, the authors appreciate that regardless of the Sievers classification, there always appears to be some level of prolapse of the fused cusps, with the caveat that bileaflet prolapse can occur in the symmetric phenotype. This finding is

\footnotetext{
From the Division of Cardiovascular and Thoracic Surgery, UTMB Health Galveston, Galveston, Tex.

Disclosures: The authors reported no conflicts of interest.

The Journal policy requires editors and reviewers to disclose conflicts of interest and to decline handling or reviewing manuscripts for which they may have a conflict of interest. The editors and reviewers of this article have no conflicts of interest.

Received for publication Dec 28, 2020; revisions received Dec 28, 2020; accepted for publication Jan 5, 2021; available ahead of print Jan 6, 2021.

Address for reprints: Abe DeAnda Jr, MD, Division of Cardiovascular and Thoracic

Surgery, UTMB Health Galveston, 301 University Blvd, Galveston, TX 77551

(E-mail: abdeanda@utmb.edu).

JTCVS Techniques 2021;7:95-7

2666-2507

Copyright (C) 2021 The Authors. Published by Elsevier Inc. on behalf of The American Association for Thoracic Surgery. This is an open access article under the CC BY-NCND license (http://creativecommons.org/licenses/by-nc-nd/4.0/).

https://doi.org/10.1016/j.xjtc.2021.01.004
}

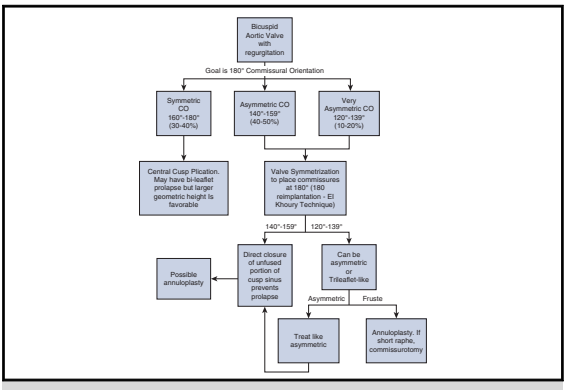

Summary of the clinical approach to a regurgitant bicuspid aorta valve.

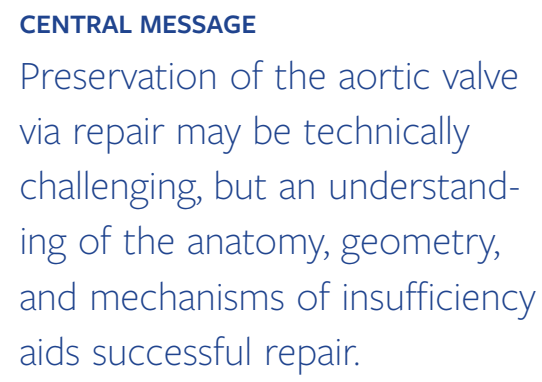

somewhat at odds with a scheme from the same institution that classifies aortic insufficiency as type I (aortic dilatation), type II (cusp prolapse), or type III (restrictive), although overlap is frequent.

After an extensive preoperative and intraoperative evaluation of the valve geometry, Jahanyar and colleagues present their algorithm and approach for repair. We have attempted to summarize their described approach (Figure 2). As the authors note, the main objectives are to correct the prolapse and stabilize the annulus. Using the commissural orientation approach, the first objective is achieved with symmetrization of the commissures, because this maximizes the cusp tissue available for coaptation. The cusps can then be repaired, typically with plication. The second objective is stabilizing the annulus. There are several approaches to stabilizing the annulus, including partial and complete annuloplasty repair, and if type I insufficiency is part of the etiology, then valve-sparing root replacement might be necessary to deal with the aortopathy as well as to fixate the annulus. ${ }^{5}$

The group at Cliniques Universitaires Saint-Luc has been repairing aortic valves since the 1990s, and their contributions to our understanding of the anatomy and function of the aortic valve and associated components have been invaluable. The commissural reorientation approach to the BAV will add another approach to our options. These procedures are technically challenging requiring a deep understanding of the related anatomy, and currently have unknown durability, predictable repairability, and 


\begin{tabular}{|c|c|c|c|c|c|c|}
\hline \multirow{2}{*}{ Al Class } & \multicolumn{4}{|c|}{$\begin{array}{c}\text { Type I } \\
\text { Normal cusp motion with FAA dilatation or cusp perforation }\end{array}$} & \multirow{2}{*}{$\begin{array}{l}\text { Type II } \\
\text { Cusp } \\
\text { Prolapse }\end{array}$} & \multirow{2}{*}{$\begin{array}{l}\text { Type III } \\
\text { Cusp } \\
\text { Restriction }\end{array}$} \\
\hline & la & $\mathrm{lb}$ & Ic & Id & & \\
\hline \multicolumn{7}{|l|}{ Mechanism } \\
\hline $\begin{array}{c}\text { Repair } \\
\text { Techinques } \\
\text { (Primary) }\end{array}$ & $\begin{array}{c}\text { STJ } \\
\text { remodeling } \\
\text { Ascending } \\
\text { aortic graft }\end{array}$ & $\begin{array}{c}\text { Aortic Valve } \\
\text { sparing: } \\
\text { Reimplantation } \\
\text { or } \\
\text { Remodeling } \\
\text { with SCA }\end{array}$ & SCA & $\begin{array}{c}\text { Patch } \\
\text { Repair } \\
\text { Autologous or } \\
\text { bovine } \\
\text { pericardium }\end{array}$ & $\begin{array}{c}\text { Prolapse } \\
\text { Repair } \\
\text { Plication } \\
\text { Triangular } \\
\text { resection } \\
\text { Free margin } \\
\text { Resuspension } \\
\text { Patch }\end{array}$ & $\begin{array}{c}\text { Leaflet } \\
\text { Repair } \\
\\
\text { Shaving } \\
\text { Decalcificatio } \\
\text { Patch }\end{array}$ \\
\hline (Secondary) & SCA & & $\begin{array}{c}\text { STJ } \\
\text { Annuloplasty }\end{array}$ & SCA & SCA & SCA \\
\hline
\end{tabular}

FIGURE 1. El Khoury functional classification of aortic insufficiency (AI). FAA, Functional aortic annulus; STJ, sinotubular junction; SCA, subcommissural annuloplasty. Adapted from Boodhwani et al. ${ }^{2}$

reproducibility. This mirrors what was said decades ago regarding mitral valve repair.

\section{References}

1. de Kerchove L, Boodhwani M, Glineur D, Poncelet A, Rubay J, Watremez C, et al. Cusp prolapse repair in trileaflet aortic valves: free margin plication and free margin resuspension techniques. Ann Thorac Surg. 2009;88:455-61.

2. Boodhwani M, de Kerchove L, Glineur D, Poncelet A, Rubay J, Astarci P, et al. Repair-oriented classification of aortic insufficiency: impact on sur- gical techniques and clinical outcomes. J Thorac Cardiovasc Surg. 2009; 137:286-94.

3. Jananyar J, El Khoury G, de Kerchove L. Commissural geometry and cusp fusion insights to guide bicuspid aortic valve repair. J Thorac Cardiovasc Surg Tech. 2021;7:83-92.

4. Sievers HH, Schmidtke C. A classification system for the bicuspid aortic valve from 304 surgical specimens. J Thorac Cardiovasc Surg. 2007;133:1226-33.

5. El Khoury G, Vanoverschelde J-L, Glineur D, Pierard F, Verhelst RR, Rubay J, et al. Repair of bicuspid aortic valves in patients with aortic regurgitation. Circulation. 2006;114(Suppl I):I610-6. 


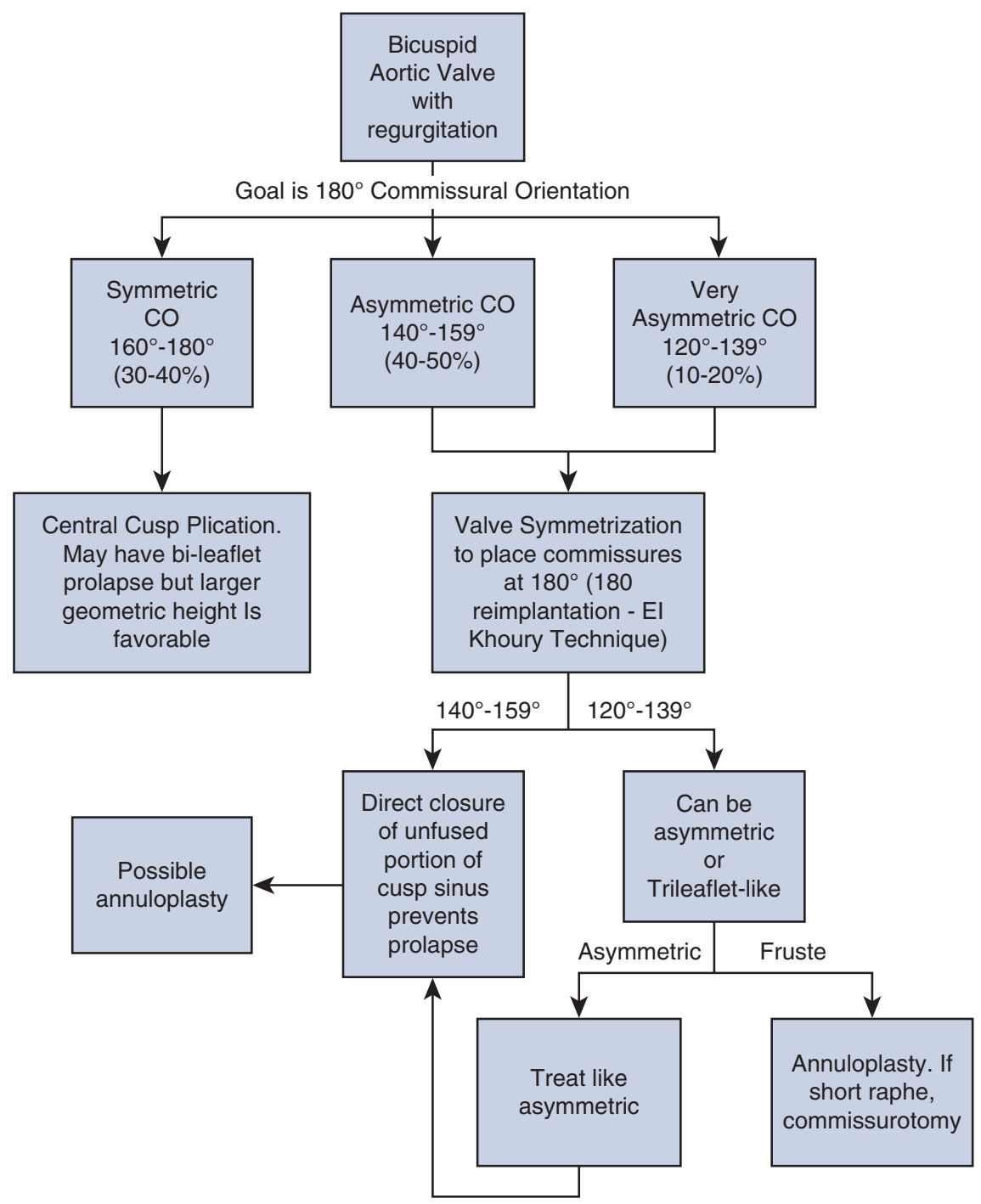

FIGURE 2. Summary of the clinical approach to a regurgitant bicuspid aorta valve. 